\title{
Biochemical, DNA and Electron Microscopic Changes in Carbamate Exposed Workers
}

\author{
Malti Singh $^{1}$, Neetu Bhardwaj ${ }^{1}$, Arvind Preet Kaur ${ }^{2}$ and Kuldip Singh ${ }^{3}$ \\ ${ }^{1}$ Department of Biotechnology, Dolphin (PG) College of life Sciences, Chunni Kalan, \\ Punjab, India \\ ${ }^{2}$ Department of Horticulture, Punjab Agricultural University Ludhiana, Punjab, India \\ ${ }^{3}$ Department of Biochemistry, Govt. Medical College, Amritsar, Punjab, India
}

KEYWORDS Carbamates, DNA, Lipid Peroxidation, Glutathione

\begin{abstract}
Carbamates are the type of pesticides which are used mainly in agriculture as insecticides, fungicides, herbicides, nematocides or sprout inhibitors. In addition they are used as biocides in industries and other applications and in household products. They are mainly used to improve the crop yield but their use is also linked to various harmful effects to the users and farmers exposed to them. Their exposure is linked to free radical generation \& thus oxidative stress and various types of damages to biomolecules such as DNA, lipids, proteins etc. So, the aim of present study was to evaluate the effect of carbamate exposure on the oxidative stress marker like lipid peroxidation and antioxidant reduced glutathione along with change in RBC membrane, protein profile and genotoxicity by DNA fragmentation analysis. In the present work, we observed a significant increase $(\mathrm{p}<0.001)$ in lipid peroxidation while the levels reduced glutathione was significant decrease in pesticide exposed workers compared to control healthy subjects. Electron microscopy of RBC showed available degree of cellular changes and bands of some small molecular weight protein get disappeared and some bands were over expressed in the pesticide exposed samples. The damage to DNA molecule resulting in fragmentation of genomic DNA has been seen in pesticide exposed samples. Results of present study suggested that there is an initiation of oxidative stress in carbamate exposed worker and hence could be responsible for the onset of damage and eventual loss.
\end{abstract}

\section{INTRODUCTION}

The economy of developing countries like India is agricultural based, but pests act as main challenge in maintaining the economy. So, different pesticides are being used by the farmers for so many years all over the world. The various classes of pesticides include the organophosphates, carbamates, pyrethroids, organochlorines etc Davis et al. (1993). Carbamates are such pesticides which are chemically, derivatives of carbamaic acid. They are used in agriculture as insecticides, fungicides, herbicides, nematocides or sprout inhibitors Ecobichon (1996). In addition, they are used as biocides for industrial or other applications and in household products. The use of pesticides beyond limits may cause various health problems to mankind. The use of pesticides exerts not only physical and instant effects; but also, long lasting effects

Address for correspondence:

Dr. Kuldip Singh

Senior Lecturer

Department of Biochemistry, Govt. Medical College,

Amritsar, Punjab, India

Mobile: 09417355095

E-mail: drkuldip08@gmail.com with psychological changes. Apart from visual and superficial effects, some hidden but very adverse effects such as biochemical and physiological changes are also related to pesticide exposure, resulting into toxic events Patil et al. (2003)

The major toxic phenomenon includes generation of free radicals, which have profound harmful effects on the cellular system e.g. peroxidation of membrane, alterations in key enzymatic activities as well as genotoxicity Feng et al. (1997). The continuous and unsafe use of carbamates results in the imbalance between the generation of reactive oxygen species (ROS) and the biological system's ability to detoxify the reactive intermediates resulting into oxidative stress. The biological antioxidant defense system plays a vital role in constituting natural defense against endogenous generated ROS and other free radicals (Kaplowitz and Tsukamoto 1996; Urso and Clarkson 2003). The overproduction of reactive free radical species and induced oxidative stress may cause damage to bimolecules such as lipids, proteins etc and thus causing improper functioning of biological system (Lennon et al. 1991; Sato et al. 1995). Physiological damage resulting from the carbamate poisoning includes 
the mononuclear and leukocyte along with various types of cancers such as skin cancer, breast cancer, brain cancer etc (Vineis et al. 1990; Slater 1995; Dolapsakis et al. 2001). Psychological effects of pesticides results in various neural disorders such as Alzheimer's disease, Parkinson's disease, Ischemia/ reperfusion neuronal injuries etc. The harmful effects of the overuse of pesticides have been noticed so far, which leads to the death of the user. So, in the present study, we wanted to evaluate oxidative stress marker like lipid peroxidation (LPO) and antioxidant such as reduced glutathione along with change in red blood cell (RBC) membrane by electron microscopy, protein profile by performing SDSPAGE and genotoxicity by using DNA fragmentation analysis.

\section{MATERIALS AND METHODS}

Subjects: 20 volunteers (males) were taken up for the present study in the age range of 20-40 years doing the seasonal spray of the 'Carbabazin' fungicide (Carbamate pesticide) without any protective equipment like gloves and masks etc. The control group consisted of 20 normal healthy male subjects with same age group (20-40 years old), who were not performing spraying activity $\&$ did not having any kind of pesticide exposure and from well socio-economic group. Consent was obtained from both the groups (both sprayers and control group subjects). Blood samples were collected in vaccuated tubes along with ethylene diamine tetra acetic acid (EDTA) as anticoagulant. The samples were preserved at $4^{\circ} \mathrm{C}$ to maintain their activities. Serum was separated out of the blood and was stored at $-20^{\circ} \mathrm{C}$ for further studies.

Preparation of Cell Lysates: Cell lysates were prepared by the method of Ceballos- Picot et al (1996) for various biochemical assays and stored at $-20^{\circ} \mathrm{C}$.

\section{Biochemical Assays}

1. Malondialdehyde (MDA): MDA level in serum was estimated by measuring the pink colored chromophore formed by the reaction of thiobarbituric acid with malondialdehyde according to the method of Buege and Aust (1978). The absorbance was read at $532 \mathrm{~nm}$ and the results were expressed as nmoles of MDA formed $/ \mathrm{min} / \mathrm{mg}$ protein.

2. Glutathione Reduced (GSH): GSH levels were estimated by the method of Moron et al (1979) using 5-5' dithiobis-2-notrobenzoic acid. The results were recorded as mmoles $\mathrm{GSH} / \mathrm{mg}$ protein.

3. Protein: The proteins levels were estimated by applying the method of Lowry et al (1951).

4. Blood Urea: Urea levels were estimated by applying End Point Diacetyl monoxime (DAM) method (Kit: Cat no. TC-020630).

5. SDS-PAGE: The protein profile was studied by performing SDS-PAGE Laemmli (1970).

6. DNA Fragmentation: DNA was isolated by the standardized Phenol- Chloroform method Maniatis (1989) and then the changes in the genomic DNA were noticed by performing Agarose gel Electrophoresis.

7. Scanning Electron Microscopy (SEM) of blood samples was done at the "Sophisticated Analytical Instrumentation Facility (DST)" of the department of Anatomy in All India Institute of Medical Sciences (AIIMS), New Delhi.

Statistical Analysis: Numerical data from diabetic patients and control were compared using Students " $t$ " test. Values were expressed as mean values \pm standard deviation (SD). Sigma stat version 3.0 was used for statistical analysis. "P" value of less than 0.05 was considered to indicate statistical significance.

\section{RESULTS AND DISCUSSION}

The present study made an attempt to evaluate the local changes due to free radicals by measuring MDA (representing lipid peroxidation) and endogenous scavenger glutathione in carbamate exposed persons. MDA, a well known index of lipid peroxidation was found to be significantly increased $(\mathrm{p}<0.001)$ from $1.97 \pm 0.55$ to $3.19 \pm 0.50 \mathrm{nmoles}$ of MDA formed $/ \mathrm{min} / \mathrm{mg}$ protein in carbamate exposed persons and by $61.92 \%$ with respect to control subjects (Table1). A significant increase in peroxidation of membrane lipids could be due production of free radicals, which occurs when $\mathrm{OH}$ radical produced in close vicinity to membrane and attacks the fatty acid side chains of membrane phospholipids preferentially polyunsaturated fatty acid chains, which further undergoes molecular rearrangements to produce conjugated diene structure that can have various fates that is such two radicals can combine to form a covalent bound or they can also react with proteins. However under 
physiological conditions the most likely fate of carbon centred radicals is to combine with oxygen to create yet another radical that is peroxyl radical. Peroxyl radicals are reactive enough to attack adjacent fatty acid side chains, abstracting hydrogen to produce yet another carbon central radical and so, the chain reaction continues. One $\mathrm{OH}$ radical can result in the conversion of many hundred fatty acid side chains into lipid peroxides (Griveau et al. 1995; Gill et al. 2002; Singh et al. 2007). Accumulated lipid hydroperoxides can also decompose to yield a range of highly cytotoxic products. So, a significant increase in lipid peroxidation in carbamate exposed worker might lead to susceptibility of the biomembrane and cause tissue injury. Glutathione is an important antioxidant metabolite, which counters oxidative stress by eliminating the compounds responsible for lipid peroxidation or by increasing the efficiency of NADPH that protects detoxifying enzymes Read and Farris (1984). A significant decrease $(p<0.001)$ by $74.5 \%$ in carbamate exposed workers with respect to control subjects (from $0.066 \pm 0.02$ to $0.0168 \pm 0.004 \mu$ moles of $\mathrm{GSH} / \mathrm{mg}$ protein) in GSH (Table 1) and this could be due to its increased utilization in protecting 'SH' containing proteins from lipid peroxides. This observation of decrease in GSH level is in agreement with the report that inverse relationship exists in GSH and lipid peroxidation (Banerjee et al. 1999; Saveeta et al. 2009). Glutathione depletion to about $20 \%$ from its original level can impair the cells defense against the toxic action of xenobiotic and may lead to cell injury.

Blood urea level was found to be significant decrease $(p<0.001)$ by $23.1 \%$ in carbamate exposured workers compare to control group (Table 1). Similar observations were also reported by Yousef et al (2003), John (2006), Hernandez et al. (2006) as observed in present study. A significant decrease in urea level could be due to the effect of pesticide on liver functions since urea is the end product of protein metabolism Yousef et al. (2003). In the present work, we have also observed that total serum protein content get decreased by $33 \%$ in group- 2 in comparison to the control group (Table1). In 2002, Bhavan and Geraldine suggested that due to pesticide poisoning the body has to utilize the proteins to cope up with the oxidative stress and hence it could be the reason for decrease in the protein content.

In the present study, alternations in the
Table 1: Levels of lipid peroxidation, Reduced Glutathione, Protein and urea in control and Pesticide exposed samples.

\begin{tabular}{|c|c|c|}
\hline $\begin{array}{l}\text { Biochemical } \\
\text { Assays }\end{array}$ & $\begin{array}{c}\text { Group-1 } \\
{[\text { Control] }(n=20)}\end{array}$ & $\begin{array}{l}\text { Group-2 } \\
\text { [Carbamate } \\
\text { exposed] } \\
(n=20)\end{array}$ \\
\hline $\begin{array}{l}\text { Lipid Peroxidation } \\
\text { (n moles of MDA } \\
\text { formed/min/ } \\
\mathrm{mg} \text { protein) }\end{array}$ & $1.97 \pm 0.55^{\mathrm{a}}$ & $\begin{array}{c}3.19 \pm 0.50^{* *} \\
(+61.92)^{\mathrm{b}}\end{array}$ \\
\hline $\begin{array}{l}\text { Reduced Glutathione } \\
\text { ( } \mu \text { moles of GSH/ } \\
\text { mg protein) }\end{array}$ & $0.066 \pm 0.02$ & $\begin{array}{c}0.0168 \pm 0.004^{* * *} * \\
(-74.54)\end{array}$ \\
\hline Proteins (g/dl) & $8.33 \pm 0.52$ & $\begin{array}{c}5.25 \pm 0.44 * * * \\
(-36.97)\end{array}$ \\
\hline Urea $(\mathrm{mg} / \mathrm{dl})$ & $32.90 \pm 1.88$ & $\begin{array}{c}20.30 \pm 3.12 * * * \\
(-38.29)\end{array}$ \\
\hline
\end{tabular}

a- values are expressed as mean \pm S.D of 20 observations b- values in parentheses represent percentage changes compared to control

$$
* \mathrm{P}<0.05, * * \mathrm{P}<0.001
$$

pattern of appearance of DNA bands of control (Group-1) and pesticide exposed workers (Group2) was also observed by performing fragmentation of genomic DNA (Fig. 1) In the control subjects, two sharp bands appear on the top of the agarose gel electrophoresis while in

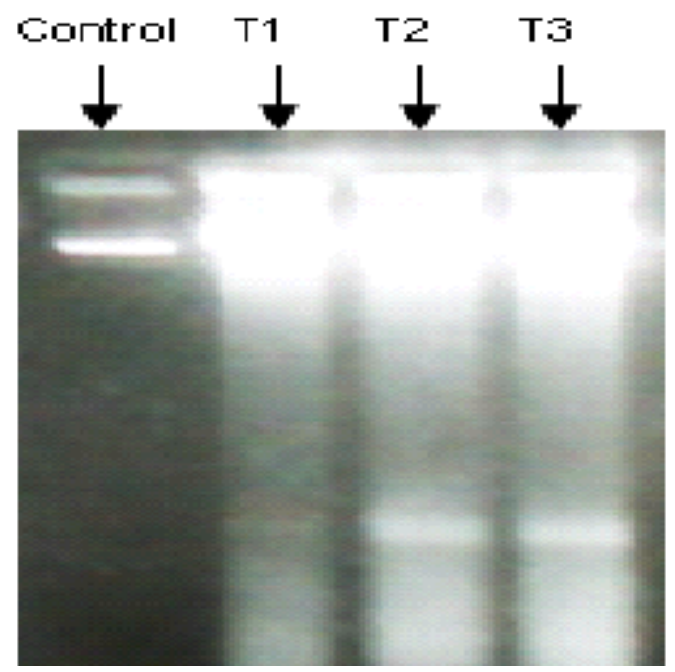

Fig. 1. Agarose gel electrophoresis of DNA in control and pesticide exposed workers

Lane Control: Normal Healthy Subjects (Group-1).

Lane T1: Sample-1 of Carbamate exposed worker (Group-2)

Lane T2: Sample-2 of Carbamate exposed worker (Group-2)

Lane T3: Sample-3 of Carbamate exposed worker (Group-2) 


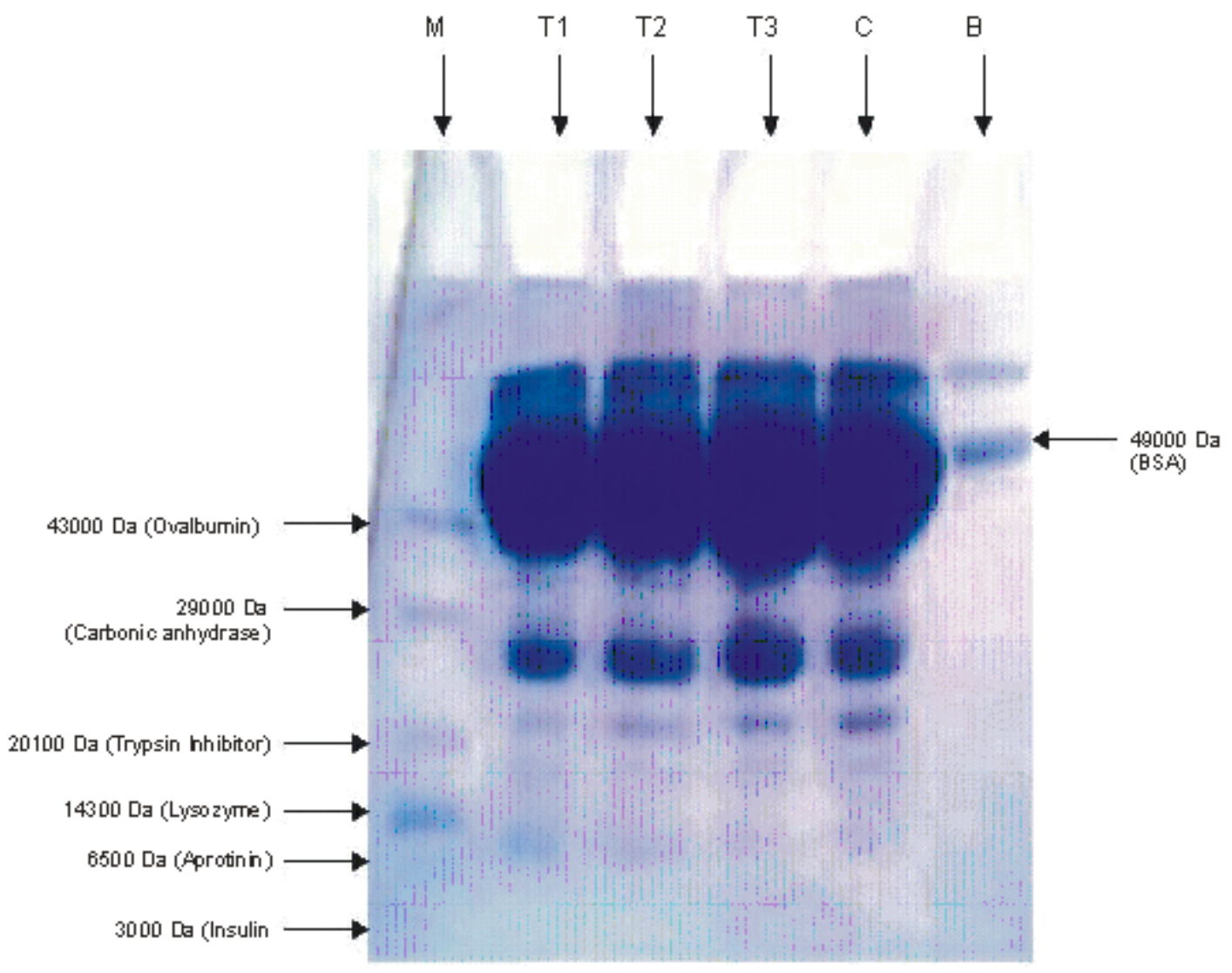

Lane-M: Marker.

Fig. 2. Protein profile in control and pesticide exposed samples

Lane-T1: Sample-1 of Carbamate exposed worker-1.

Lane-T2: Sample-2 of Carbamate exposed worker-2.

Lane-T3: Sample-3 of Carbamate exposed worker-3.

Lane-C: Control subject.

Lane-B: BSA (As Standard).

the pesticide exposed workers these two bands scattered and their position also changed. Moreover one band appears at the bottom of the agarose gel electro-phoresis of group-2 workers but this band absent in the control subjects (Fig. 1). The protein profile generated after performing the SDS-PAGE of both the pesticide exposed (Group-2) and control (Group-1) protein samples shown that the intensity of some of the bands of low molecular weight proteins get disappeared in the pesticide exposed workers (Fig. 2). These changes could be due to alteration in DNA level, which might be directly/indirectly affects the protein profile.
The scanning electron microscopic (SEM) examination of the red blood cells of both the control and pesticide exposed workers was also recorded. Scanning electron microscopic (SEM) examination of RBCs shown irregular shape and shrinkage of the membrane of the RBCs (Fig. 3). So, it is evident from these observations that the extent of oxidative stress by carbamate was able to change the RBC membrane architecture.

In conclusion, the afore mentioned observations suggested that carbamate induced oxidative stress by altering lipid peroxidation and glutathione levels in carbamate exposed workers, which finally culminating in variable degrees of 


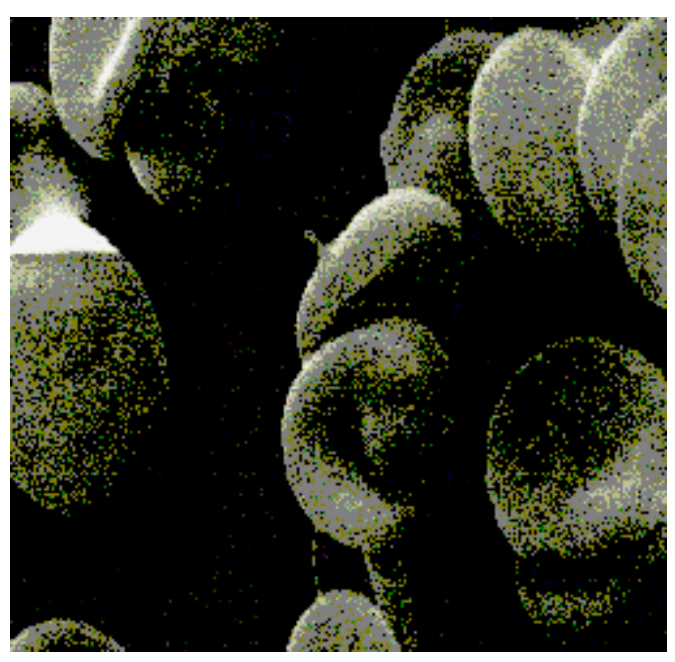

Control (Group-1)

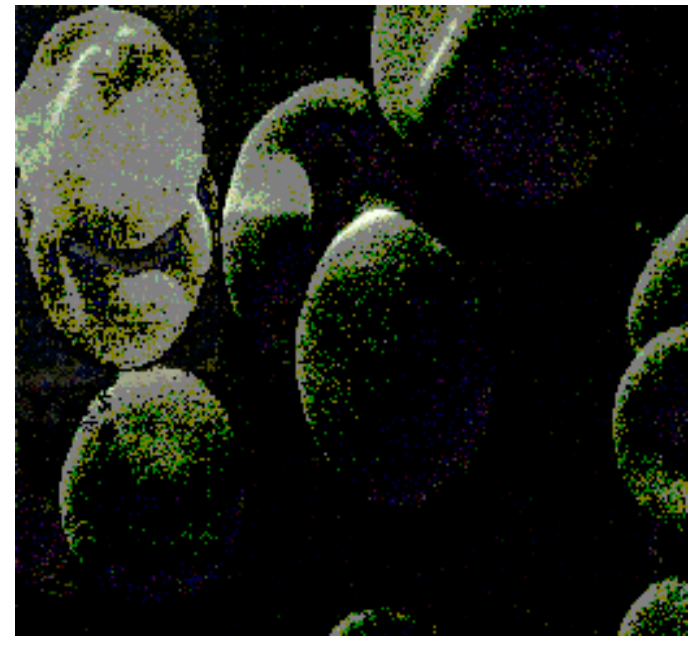

Carbamate exposed (Group-2)

Fig. 3. Scanning Electron Microscopy (SEM) of Control (Group-1) and carbamate exposed workers (Group-2) samples (Magnification 5.50 K X)

protein, DNA and RBC membrane insult, damage and eventual loss.

\section{REFERENCES}

Banerjee BD, Seth V, Bhattacharya A, Pasha ST, Chakraborty AK 1999. Biochemical effect of some pesticides on lipid peroxidation and free- radical scavengers. Toxicology Lett, 107: 33-47.

Bhavan PS and Geraldine P 2002. Carbaryl- induced alterations in biochemical metabolism of the prawn, Macrobrachium malcolmsonii. J Environ Biol, 23: 157-162.

Buege JA, Aust SD 1978. Microsomal lipid-peroxidation. In: Methods of Enzymology. New York and London. Academic Press, 52, pp. 302-310.

Ceballos-Picot I, Merad-Boudia M, Nicole A, Therenin M, Hellier G, Legrain S, Berr C 1996. Peripheral antioxidant enzyme activity and selenium in elderly subjects and in dementia of Alzheimer's type- Place of the extracellular glutathione peroxidase. Free Radical Biology and Medicine, 20: 579-587.

Davis JR, Brownson RC, Garcia R, Bentz BJ, Turner A 1993. Family pesticides use and childhood brain cancer. Arch Environ Contam Toxicol, 24: 87-92.

Dolapsakis G, Vlachonikolis IG, Varveris C, Tsatsakis AM 2001. Mommographic findings and occupational exposure to pesticides currently in use on crete. Eur J Cancer, 37: 1531-1536.

Ecobichon DJ 1996. Toxic effects of pesticides: In: CD Klaassen, J Doull (Eds.): Casarett, Doull's: Toxicology: The Basic Science of Poisons. $5^{\text {th }}$ Edition. New York: McMillan, pp 643-689.

Feng NK, George H, Yueh HK 1997. Protection of oxidative hemolysis by dimethyldiisoeugenol in normal and thalasemia red blood cells. Free Radical Biol Med, 12: 217-211.
Gill P, Fernando F, Angela C 2002. Encarnaction and Malondialdehyde: A possible marker of agong. Gerotol, 48: 147-159.

Griveau JF, Dumont E, Renard P, Callegari JP, Le Lannou D 1995. Reactive oxygen species, lipid peroxidation and enzymatic defense system in human spermatozoa. J Reprod Fertil, 103: 17-26.

Hernandez AF, Amparo Gomez M, Perez V, Garcia- Lario JV, Pena G, Gil F, Lopez O, Rodrigo L, Pino G, Pla A 2006. Influence of exposure to pesticides on serum components and enzyme activities of cytotoxicity among intensive agricultural farmers. Environ Res, 102: 70-76.

John PJ 2006. Alteration in certain blood parameters of fresh water Telost Mystus vittatus after chronic exposure to metasystox and sevin. Fish Physiology and Biochemistry, 33: 15-20.

Kaplowitz N, Tsukamoto H 1996. Oxidative stress and liver diseases. In: JL Boyer, RK Ockner RK (Eds.): Progress in Liver Diseases. Vol 14. Philadelphia: WB Saunders: pp. 131-159.

Laemmli UK 1970. Cleavage of structural protein during the assembly of head of bacteriophage T4. Nature, 277: 680-685.

Lennon SV, Martin SJ, Cotter TG 1991. Dose dependent induction of apoptosis in human tumor cell lines by widely diverging stimuli. Cell Prolif, 24: 203-214.

Lowry OH, Rosenbrough NJ, Farr AL, Randall RJ 1951. Protein measurement with folin phenol reagent. $J$ Biol Chem, 239: 2370-2385.

Maniatis T, Sambrook J, Fritsch EF 1989. Molecular Cloning: A Laboratory Manual. New York: American Medical Association (AMA).

Moron MJ, Diperrie JW, Manner KB 1979. Levels of glutathione, glutathione reductase and glutathioneS- transferase by limited proteolysis. J Biol Chem, 260: 577 - 589.

Patil JA, Patil AJ, Govindwar SP 2003. Biochemical 
effects of pesticides. Indian journal of Clinical Biochemistry, 18: 16-22.

Read, DJ, Farris MW 1984. Glutathione depletion and susceptiblility. Pharmacol Rev, 36: 25S-33S.

Sato N, Iwata S, Nakamura K, Hori T, Mori K, Yadoi J 1995. Thiol mediated redox regulation of apoptosis. J Immunol, 154: 3194-3203.

Saveeta Aggarwal, Kuldip Singh, Madhu Nagpal, Amrit Kaur, Ahluwalia P 2009. Studies on the effect of lycored supplementation (Lycopene) on lipid peroxidation and reduced glutathione in pregnancy induced hypertensive patients. Bio Med. Res, 20: 54-58.

Singh VK, Reddy MMK, Jyoti, Kesavachandran C, Rastogi SK, Siddiqui MKJ 2007. Biomonitoring of organochlorines, glutathione, lipid peroxidation and cholinesterase activity among pesticide sprayers in mango orchards. Clinica Chimica Acta, 377: 268272.

Slater AF, Stefen C, Nobel I, Van Den Dobbelsteen DJ, Orrenius S 1995. Signaling mechanism and oxidative stress in apoptosis. Toxicol Lett, 82/83: 149-153.

Urso ML, Clarkson PM 2003. Oxidative stress, exercise and antioxidant supplementation. Toxicology, 189: 41-54.

Vineis P, Settimi L, Seniori- Constantini A 1990. Esposizione, a fitofarmacie rischio oncogeno. Med Lav, 81: 363-372.

Yousef MI, El-Demerdash FM, Kamel KI, Al-Saleh KS 2003. Changes in some hematological and biochemical indices of rabbit induced by isoflavones and cypermethrin. Toxicology, 189: 223-234. 